\title{
GLOSA DO UCHWALY SĄDU NAJWYŻSZEGO Z DNIA \\ 24 SIERPNIA 2017 R., SYGN. AKT III CZP 20/17, W SPRAWIE KOMPENSACJI WYDATKÓW PONIESIONYCH PRZEZ POSZKODOWANEGO NA NAJEM POJAZDU ZASTĘPCZEGO
}

\begin{abstract}
Streszczenie. W glosie do uchwały Sądu Najwyższego dotyczącej problematyki kompensacji wydatków poczynionych na najem zastępczego środka komunikacji przez poszkodowanego w wypadku komunikacyjnym wskazano wątpliwości, jakie mogą się nasuwać w kontekście dotychczasowego orzecznictwa i praktyki, a także sprzeczności wewnętrzne uzasadnienia tej uchwały. Teoretycznie poprawnemu tokowi rozumowania przedstawionemu przez Sąd Najwyższy przedstawiono argumenty płynące z praktyki i doświadczenia życiowego użytkowników pojazdów mechanicznych, uwypuklające idealistyczną wizję funkcjonowania rynku najmu pojazdów zastępczych, przedstawioną przez skład orzekający.

Słowa kluczowe: kompensacja wydatków na pojazd zastępczy, najem pojazdu, linia orzecznicza w sprawie wypadków komunikacyjnych, współdziałanie ubezpieczonego z ubezpieczycielem przy likwidacji szkody, wydatek celowy i ekonomicznie uzasadniony.
\end{abstract}

\section{WPROWADZENIE}

Uchwała Sądu Najwyższego z dnia 24 sierpnia 2017 r. (III CZP 20/17, OSNC 2018, nr 6, poz. 56) dalej zwana „Uchwałą” jest jednym z najnowszych rozstrzygnięć Sądu Najwyższego w zakresie problematyki związanej z kompensacją wydatków poczynionych na najem zastępczego środka komunikacji przez poszkodowanego w wypadku komunikacyjnym. Wobec zagadnień poruszonych w uzasadnieniu niniejszej Uchwały, zasługuje ona na szczególną uwagę, ponieważ kwestie związane z zapewnieniem pojazdu zastępczego budzą wątpliwości zarówno doktryny prawa cywilnego, jak i wymiaru sprawiedliwości.

$\mathrm{Z}$ pierwszym przełomowym orzeczeniem $\mathrm{w}$ tej tematyce mieliśmy do czynienia przy okazji wydania uchw. SN (7) z 17.11.2011 r. (III CZP 5/11, OSNC 2012, nr 3, poz. 28), umożliwiającej dochodzenie zwrotu kosztów poniesionych na najem pojazdu zastępczego również osobom fizycznym, w wyniku której można było zaobserwować znaczny wzrost powództw z żądaniem zapłaty odszkodowania obejmującego właśnie zwrot wydatków na najem pojazdu zastępczego.

\footnotetext{
*Uniwersytet Łódzki, Wydział Prawa i Administracji, michalpytkowski89@gmail.com.
} 
W głównej mierze za sprawą tego wzrostu powództw, a także braku ugruntowanej linii orzeczniczej, wyroki sądów powszechnych, od czasu podjęcia przez SN uchwały o sygnaturze akt III CZP 5/11, charakteryzuje skrajna rozbieżność, której przejaw stanowił podstawę do zadania przez Sąd Okręgowy pytania prawnego, w odpowiedzi na które SN podjął Uchwałę. Uchwała ta miała stanowić panaceum na rozchwiane orzecznictwo poprzez zarysowanie, w oparciu o uchwałę w sprawie III CZP 5/11, linii orzeczniczej w sprawach dotyczących najmu pojazdu zastępczego. W mojej ocenie zadanie to udało się SN zrealizować w stopniu niewystarczającym, wobec czego niniejsza glosa przyjmuje charakter krytyczny.

\section{STAN FAKTYCZNY ORAZ ROZSTRZYGNIECCIE SN}

Uchwała zapadła na skutek pytania prawnego wystosowanego przez jeden z Sądów Okręgowych rozpoznających apelacje w połączonych sprawach, w których przedsiębiorcy żądali zasądzenia od ubezpieczycieli OC sprawców wypadków drogowych odszkodowań z tytułu naprawienia szkody w postaci kosztów najmu pojazdu zastępczego. Powodowie wskazali, że w postępowaniu likwidacyjnym ubezpieczyciele pokryli jedynie część kosztów najmu. Sądy Rejonowe rozpatrujące sprawy w pierwszej instancji, przed ich połączeniem, mimo niemal tożsamego stanu faktycznego, wydały całkowicie odmienne wyroki.

W jednej ze spraw Sąd Rejonowy uwzględnił powództwo, odrzucając argumentację ubezpieczyciela, który wywodził, że w ramach ubezpieczenia OC nie jest zobowiązany do pokrycia kosztów najmu pojazdu zastępczego wykraczających poza koszty, które poniósłby poszkodowany, gdyby skorzystał z przedstawionej mu przez ubezpieczyciela propozycji najmu pojazdu od współpracującego z nim przedsiębiorcy.

W drugiej sprawie Sąd Rejonowy powództwo oddalił, podzielając argumentację ubezpieczyciela, który twierdził, że w ramach ubezpieczenia OC nie jest zobowiązany do pokrycia kosztów najmu pojazdu zastępczego wykraczających poza koszty, które poniósłby poszkodowany, gdyby skorzystał z propozycji najmu przedstawionej mu przez ubezpieczyciela. Sąd Rejonowy uznał, że ponosząc wyższe koszty najmu, poszkodowany przyczynił się do zwiększenia szkody.

Rozpatrując wyżej wymienione sprawy Sąd Okręgowy, wskazując na rozbieżności w orzecznictwie sądów powszechnych dotyczące tego, czy ciążący na poszkodowanym obowiązek minimalizacji szkody i obowiązek współdziałania z dłużnikiem przy wykonaniu zobowiązania, skierował do SN pytanie prejudycjalne'.

${ }^{1}$ Treść pytania prejudycjalnego: „Czy w ramach obowiązku minimalizacji szkody, poszkodowanemu który nie skorzystał z oferty najmu pojazdu od ubezpieczyciela OC posiadaczy pojazdów mechanicznych, oferującego mu bezpłatnie pojazd zastępczy według stawek niższych, 
Rozstrzygnięcie pytania prejudycjalnego, o którym mowa powyżej, już na samym wstępie wskazuje na uchwałę III CZP 5/11 wspomnianą na początku niniejszej glosy z zaznaczeniem, że umożliwiła ona domaganie się zwrotu kosztów najmu pojazdu zastępczego osobom nieprowadzącym działalności gospodarczej. Nawiązując do treści uchwały III CZP 5/11 SN podkreślił, że odpowiedzialność ubezpieczyciela OC w żadnym wypadku nie jest nieograniczona i obejmuje jedynie ,celowe i ekonomicznie uzasadnione wydatki na najem pojazdu zastępczego”, a także, wobec obowiązku wierzyciela zapobiegania szkodzie i zmniejszania jej rozmiarów, nie wszystkie wydatki pozostające w związku przyczynowym z wypadkiem komunikacyjnym powinny być kompensowane. Co za tym idzie, ochrona interesu poszkodowanego powinna mieścić się w rozsądnych granicach. SN, bazując na uchwale III CZP 5/11 stwierdził, że nie mogą być uznane za celowe i ekonomicznie uzasadnione wydatki, które nie są konieczne do wyeliminowania negatywnego następstwa majątkowego w postaci utraty możliwości korzystania z pojazdu, gdyż następstwo to może być wyeliminowane w inny, mniej uciążliwy dla dłużnika sposób. Jeżeli zatem ubezpieczyciel proponuje poszkodowanemu skorzystanie z pojazdu zastępczego równorzędnego pod istotnymi względami pojazdowi uszkodzonemu albo zniszczonemu, zapewniając pełne pokrycie kosztów jego udostępnienia, poszkodowany powinien z takiej oferty skorzystać. Jeżeli mimo to poszkodowany decyduje się na poniesienie wyższych kosztów najmu, to koszty te będą podlegały zwrotowi tylko wtedy, gdy wykaże szczególne racje, przemawiające za uznaniem ich właśnie za „celowe i ekonomicznie uzasadnione”.

Co istotne w kontekście dalszej części niniejszej glosy, SN stwierdził, że „poniesienie wyższych kosztów nie uzasadnia prostota skorzystania z oferty złożonej np. przez przedsiębiorcę prowadzącego warsztat naprawczy. Konieczność dodatkowego kontaktu z ubezpieczycielem nie może być uznana za niedogodność, która uzasadnia poniesienie wyższych kosztów najmu". Ponadto, w ramach ciążącego na poszkodowanym obowiązku minimalizacji szkody i współdziałania z ubezpieczycielem mieści się obowiązek niezwłocznego zasięgnięcia informacji co do tego, czy ubezpieczyciel może zaproponować poszkodowanemu pojazd zastępczy. Na dodatek SN wskazał również, że takie okoliczności, jak np. opóźnienie w dostarczeniu pojazdu albo zaproponowanie samochodu niższej klasy, nie mogą być decydujące w wyborze droższej oferty.

SN również stwierdził, że przeciwko przedstawionemu w Uchwale stanowisku nie ma przemawiać wystarczająco silnie przyjmowany w orzecznictwie SN pogląd, że odpowiedzialnością ubezpieczyciela objęte są koszty naprawy pojazdu ustalone według cen, którymi posługuje się swobodnie wybrany przez poszkodowanego warsztat naprawczy, choćby były wyższe od średnich cen, jeżeli tylko odpowiadają cenom stosowanym przez usługodawców na lokalnym rynku. SN

od oferowanych przez wynajmującego, przysługuje zwrot faktycznie poniesionych wydatków na najem pojazdu zastępczego?" 
przyjął, że naprawa pojazdu służy bezpośrednio wyeliminowaniu już istniejącej szkody majątkowej, zatem interes poszkodowanego podlega intensywniejszej ochronie, niż w przypadku wydatków na najem pojazdu zastępczego, które nie służą wyrównaniu szkody, a jedynie wyeliminowaniu negatywnych następstw majątkowych doznanych przez poszkodowanego w wyniku uszkodzenia pojazdu. Dlatego też wymagania dotyczące pokrycia obu kategorii kosztów różnią się.

\section{NAWIĄZANIE DO STANOWISKA INNYCH GLOSATORÓW}

W swojej glosie do Uchwały E. Kowalewski i M. Ziemiak w zakresie sformułowanych przez siebie pierwszych dwóch tez, wskazali na zasługujące na aprobatę rozróżnienie stopnia intensywności ochrony interesów poszkodowanych, w zależności od rodzaju uszczerbku majątkowego, a także konsekwencję SN w popieraniu stanowiska wygłoszonego w uchwale III CZP 5/11. W zakresie tych tez, należy się w pełni zgodzić ze wspomnianymi autorami unikając dublowania trafnie sformułowanych spostrzeżeń. Jednak w zakresie trzeciej tezy wskazali, że „Uchwała może stać się katalizatorem dla szerszego stosowania formuły współpracy zakładów ubezpieczeń z przedsiębiorcami trudniącymi się zawodowo wypożyczaniem aut. To z kolei może się przyczynić do stabilizacji zarówno stawek czynszu najmu, jak i wypracowaniu pewnych zwyczajowych standardów dotyczących udostępniania poszkodowanym zastępczych środków komunikacji”, z czym, w połączeniu z fragmentami Uchwały, do których ta teza nawiązuje, należy się nie zgodzić.

\section{OCENA ROZSTRZYGNIĘCIA}

\subsection{Odejście od dotychczasowej praktyki}

W dotychczasowej praktyce SN, poczynając od uchwały III CZP 5/11, dominowała tendencja, iż każda kolejna uchwała poszerzała zakres podmiotów i przypadków w których to poszkodowani mogli uzyskać odszkodowanie z tytułu najmu pojazdu zastępczego. Poczynając od wspominanej uchwały III CZP 5/11, gdzie SN uznał, że poszkodowanemu należy się odszkodowanie za wynajem pojazdu zastępczego, gdy uszkodzony pojazd służył mu nie tylko do prowadzenia działalności gospodarczej, ale również do innych celów oraz że nie ma znaczenia dla odszkodowania, czy poszkodowany mógł korzystać z komunikacji zbiorowej, czy też nie. Poprzez uchw. SN z 22.11.2013 r. (III CZP 76/13, OSNC 2014, nr 9, poz. 85) w której SN przesądził o tym, że odszkodowanie obejmuje celowe i ekonomicznie uzasadnione wydatki na wynajem pojazdu zastępczego poniesione przez poszkodowanego w okresie niezbędnym do nabycia innego pojazdu mechanicznego. Kolejno w uchw. z 30.11.2016 r. (III CZP 74/16, OSNC 2017, nr 7-8, 
poz. 82) SN wskazał, że ubezpieczycielowi, który pokrył koszty najmu pojazdu zastępczego w ramach umowy ubezpieczenia Assistance przysługuje roszczenie regresowe wobec ubezpieczyciela sprawcy szkody.

Natomiast w glosowanej Uchwale SN zmienił dotychczasową tendencję poszerzania uprawnień poszkodowanych w zakresie możliwości zaspokojenia swoich roszczeń z ubezpieczenia OC ograniczając ich swobodę w wyborze najemcy, od którego mogą wynająć samochód zastępczy. Ograniczenie to przejawia się w stwierdzeniu SN, że ,istnieje bowiem obowiązek wierzyciela zapobiegania szkodzie i zmniejszenia jej rozmiarów". Wobec tego w przypadku, gdy poszkodowany odmawia skorzystania z propozycji wynajęcia pojazdu zastępczego, którą otrzymał od ubezpieczyciela za wskazaną przez ubezpieczyciela kwotę, a następnie wynajmuje pojazd za kwotę wyższą, to takie zachowanie poszkodowanego należy uznać za przyczynienie się do zwiększenia szkody i nie może on uzyskać odszkodowania $\mathrm{w}$ wysokości przekraczającej koszty najmu pojazdu oferowanego przez ubezpieczyciela, chyba że udowodni, iż poniesienie wyższych kosztów było celowe i ekonomicznie uzasadnione.

W nawiązaniu do akapitu powyżej, należy wskazać, że Uchwała, jak pośrednio wskazał sędzia sprawozdawca Roman Trzaskowski, będący członkiem składu orzekającego, słowami: „nie wszystkie wydatki związane z najmem auta zastępczego - mogą być refundowane. Uchwała dzisiejsza chroni zatem ubezpieczyciela przed ponoszeniem nieuzasadnionych kosztów, a poszkodowany ma pewność, że może wynająć auto bezkosztowo. Natomiast jeżeli poszkodowany wynajmie auto zastępcze na własną rękę na mniej korzystnych warunkach, to musi się liczyć z tym, że poniesie częściowo koszty"2 może nadmiernie ingerować w zasady konkurencji na rynku najmu pojazdów zastępczych. Jej brzmienie, w szczególności poprzez sformułowanie zastosowane w Uchwale: ,nie jest bowiem istotne to, czy propozycja ubezpieczyciela jest najtańsza, lecz to, że jest przez niego akceptowana" faworyzuje ubezpieczycieli w relacjach z przedsiębiorcami trudniącymi się najmem pojazdów zastępczych, wprowadzając de facto obowiązek wyboru przez poszkodowanego pojazdu oferowanego przez ubezpieczyciela, w sytuacji nie godzenia się $\mathrm{z}$ dopłatą w zakresie różnicy między wyższą ceną najmu pojazdu swobodnie wybranego do pojazdu oferowanego przez ubezpieczyciela.

W wyniku zapadnięcia Uchwały, punktem odniesienia przy określaniu właściwej ceny za najem pojazdu zastępczego, nie będzie, tak jak do tej pory, cena pojazdu tego samego rodzaju na rynku lokalnym, ale cena oferowana za ten pojazd przez ubezpieczyciela. Odejście od sposobu określania ceny właściwej w oparciu o warunki rynkowe jest swoistym novum nie tylko w polskiej, ale i europejskiej przestrzeni prawnej. Dla przykładu, w prawie niemieckim, które zapewnia bardzo szeroką ochronę interesów osób poszkodowanych w wypadkach

${ }^{2}$ Wypowiedź cytowana w: https://www.prawo.pl/prawnicy-sady/sn-wynajecie-drozszegoauta-zastepczego-musi-byc-racjonalne,71776.html [dostęp: 24.03.2020]. 
komunikacyjnych, poszkodowany jest uprawniony do żądania naprawienia szkody odpowiadającej poniesionym kosztom najmu pojazdu zastępczego na czas naprawy uszkodzonego pojazdu (Borysiak, Trzaskowski 2017, 45 i n.) jeśli koszty te mieszczą się w dolnych granicach cen dostępnych na rynku lokalnym (Larenz 1987, 496), przy czym wyróżnić należy brak obowiązku poszkodowanego do przeprowadzenia badań rynkowych (Krüger 2012, 423), co zdaje się dawać dużą swobodę w wyborze pojazdu zastępczego. Podobne zasady przyjęto w prawie austriackim, gdzie zdaniem większości doktryny żądanie naprawienia szkody w postaci najmu pojazdu zastępczego nie podlega szczególnym ograniczeniom. Jedynie część autorów zaostrza nieco kryteria uważając, że poszkodowany musi się zachowywać jak „rozumny, rozsądnie kalkulujący człowiek, który unika szczególnie wygórowanych kosztów" (Koziol, Bydlinski, Bollenberger 2017, 1577 i n.). Podobne stanowisko przyjmuje doktryna oraz orzecznictwo francuskie, wskazując, że wydatki na najem pojazdu zastępczego nie powinny być wygórowane i powinny być utrzymane w rozsądnych granicach (Borysiak, Trzaskowski 2017, $62 \mathrm{i} \mathrm{n}$.), nie stwarzając przy tym obowiązku skorzystania $\mathrm{z}$ oferty ubezpieczyciela. Na podstawie przytoczonych systemów prawnych widać, że przyjęcie przez SN jako punkt odniesienia przy określaniu właściwej ceny za najem pojazdu zastępczego ceny oferowanej przez ubezpieczyciela, nie znajduje oparcia w innych, zbliżonych do polskiego, systemach prawa cywilnego.

Wobec treści Uchwały oraz jej omówienia przez sędziego sprawozdawcę R. Trzaskowskiego Uchwała, owszem stanie się „katalizatorem dla szerszego stosowania formuły współpracy zakładów ubezpieczeń z przedsiębiorcami trudniącymi się zawodowo wypożyczaniem aut", ale będzie to skutkowało wykształceniem, a następnie umocnieniem linii orzeczniczej potwierdzającej obowiązek zawierania umowy $\mathrm{z}$ ubezpieczycielem $\mathrm{w}$ zakresie najmu pojazdu zastępczego, tym samym stawiając ubezpieczyciela na nadmiernie uprzywilejowanej pozycji gospodarczej względem przedsiębiorców wynajmujących pojazdy, a ponadto oddali nas od praktyk stosowanych w systemach prawnych, z których genetycznie wywodzi się polskie prawo cywilne.

Utrata znaczenia ceny na rynku lokalnym najmu pojazdów za sprawą Uchwały sprawi, że przedsiębiorcy trudniący się najmem pojazdów zastępczych będą zmuszeni, dla utrzymania pozycji na rynku, prowadzić swoją działalność nie w oparciu o równomierny rozwój, a w oparciu o walkę o kontrakty z ubezpieczycielami. Wspomniana walka sprawi, że ubezpieczyciele będą wykorzystywali uprzywilejowaną pozycję negocjacyjną, zmuszając chętnych do zawarcia kontraktu przedsiębiorców do obniżania cen oferowanych usług, a co za tym idzie, obniżania również ich jakości.

Cytując E. Kowalewskiego i M. Ziemiaka: „To z kolei może się przyczynić do stabilizacji zarówno stawek czynszu najmu, jak i wypracowaniu pewnych zwyczajowych standardów dotyczących udostępniania poszkodowanym zastępczych środków komunikacji” (Kowalewski, Ziemiak 2018), z tym, że stawki wobec 
tak umocnionej pozycji ubezpieczyciela wcale nie muszą być korzystniejsze dla poszkodowanego ze względu na dużo wyższe, niż obecnie marże, na których zastosowanie pozwoli właśnie pozycja ubezpieczycieli zbudowana w oparciu o Uchwałę, natomiast standard, ze względu na konieczność obniżania kosztów przez przedsiębiorców trudniących się najmem pojazdów zastępczych dla pozyskania kontraktu z ubezpieczycielem, w najlepszym wypadku pozostanie na obecnym poziomie.

Dodatkowo wskazać należy, że w myśl dotychczasowej i, zdawać by się mogło, racjonalnej linii orzeczniczej, poszkodowany w kolizji lub wypadku mógł wynając samochód zastępczy u dowolnego przedsiębiorcy trudniącego się tym, na czas naprawy pojazdu lub likwidacji szkody, dbając jedynie o to, aby cena za samochód zastępczy odpowiadający klasie i standardom pojazdu uszkodzonego nie odbiegała od cen występujących powszechnie na rynku. Oczywiście w większości przypadków przyjmowano także, aby czas najmu samochodu zastępczego był rzeczywiście czasem uzasadnionym.

W Uchwale SN nie wziął w ogóle pod uwagę, że poszkodowany może kierować się różnymi kryteriami wyboru wypożyczalni oferującej pojazdy zastępcze, niekoniecznie ceną. Poszkodowany może mieć na uwadze jakość świadczonej usługi, dostępność danego rodzaju pojazdu, miejsce zwrotu pojazdu, zaufanie do danego podmiotu czy też zwyczajnie jego renomę. Wskazać bowiem należy, że celem poszkodowanego, jak najbardziej uzasadnionym, jest znalezienie się w sytuacji faktycznej maksymalnie zbliżonej do tej, w której znajdowałby się, gdyby nie zaszło zdarzenie wyrządzające mu szkodę (Krajewski 2016, 42). Przywrócenie stanu poprzedniego dla poszkodowanego musi więc zmierzać ku stworzeniu stanu gospodarczego, który by istniał w braku zdarzenia szkodzącego (Olejniczak 2018), a ten w wyniku podjęcia Uchwały będzie przez ubezpieczyciela, jako mającego przeważający wpływ na sposób naprawienia szkody, zaniżany. Nie ulega wątpliwości, że niejako „zmuszenie” poszkodowanego do skorzystania z pojazdu zastępczego wskazanego przez ubezpieczyciela sprawcy stanowi zatem nie tylko ograniczenie, ale de facto pozbawienie możliwości wyboru przez poszkodowanego sposobu naprawienia szkody, o którym mowa art. $363 \S 1$ k.c.

W kontekście wyboru sposobu naprawienia szkody powstałej w wyniku braku możliwości skorzystania z pojazdu jako wzór, a zarazem drogowskaz, którym w mojej ocenie powinien kierować się SN, należy wskazać szeroki wachlarz uprawnień zapewniony poszkodowanym w niemieckim systemie prawnym. W orzecznictwie niemieckim od kilku dekad przyjmuje się, że jeżeli właściciel uszkodzonego albo zniszczonego pojazdu zrezygnował z najmu pojazdu zastępczego, przysługuje mu uprawnienie do żądania odszkodowania za utratę możliwości korzystania z pojazdu. W takiej sytuacji przyjmuje się, że podstawą indemnizacji utraty możliwości korzystania z rzeczy jest $§ 251$ ust. 1 BGB. Wskazuje się też, że wartość używania może stanowić niezależną względem substancji rzeczy pozycję w majątku poszkodowanego (Borysiak, Trzaskowski 2017, 50 i n.). 


\subsection{Zbyt szerokie określenie obowiązku minimalizacji szkody}

SN wywiódł, że poniesienia wyższych kosztów nie uzasadnia prostota skorzystania z oferty złożonej np. przez przedsiębiorcę prowadzącego warsztat naprawczy. Konieczność dodatkowego kontaktu z ubezpieczycielem nie może być uznana za niedogodność, która uzasadnia poniesienie wyższych kosztów najmu. Co więcej, zdaniem SN, w ramach ciążącego na poszkodowanym obowiązku minimalizacji szkody i współdziałania z ubezpieczycielem mieści się obowiązek niezwłocznego zasięgnięcia informacji co do tego, czy ubezpieczyciel może zaproponować poszkodowanemu pojazd zastępczy.

W powyżej przytoczonym fragmencie Uchwały, SN zdaje się zbyt restrykcyjnie przyjmować obowiązek minimalizacji szkody przez poszkodowanego w wypadku komunikacyjnym. Dla przykładu, w doktrynie niemieckiej oraz austriackiej ${ }^{3}$ przyjęty jest pogląd, że naprawienie szkody poprzez najem pojazdu zastępczego stanowi restytucję naturalną, która nie jest ograniczona przez obowiązek poszkodowanego do zmniejszenia szkody. Zauważono bowiem, że obowiązek minimalizowania szkody nie może - w braku współzawinienia - ograniczać istniejącego roszczenia odszkodowawczego o charakterze restytucyjnym (Borysiak, Trzaskowski 2017, 45 i n.). W moim odczuciu, również SN powinien zmierzać ku łagodniejszemu traktowaniu poszkodowanego, co też stopniowo czynił w poprzednich wyrokach oraz uchwałach. To na ubezpieczycielu, po uprzedniej informacji o zdarzeniu, uzyskanej od poszkodowanego, powinien ciążyć obowiązek poinformowania o możliwości, bądź jej braku, niezwłocznego dostarczenia pojazdu zastępczego poszkodowanemu.

Art. $354 \S 2$ k.c. stanowi wprawdzie, że podstawowym obowiązkiem, jaki spoczywa na wierzycielu przy wykonywaniu zobowiązania, jest współdziałanie z dłużnikiem. Należy jednak dodać, że jest to obowiązek szczególnego rodzaju, nałożony na wierzyciela przede wszystkim w jego własnym interesie, dla umożliwienia uzyskania przez niego należnego mu świadczenia (Gniewek 2019). W tym miejscu należy przytoczyć fragment komentarza do art. 354 k.c. pod redakcją K. Osajdy stanowiący, że współdziałanie to może być rozumiane jako takie zachowanie się wierzyciela, bez którego spełnienie świadczenia przez dłużnika jest w ogóle niemożliwe albo nadmiernie utrudnione (Osajda 2017).

Dla pełnego obrazu obowiązku minimalizacji szkody nie można pominąć również brzmienia art. $826 \S 1$ k.c. ${ }^{4}$, który część doktryny uznaje, za lex specialis w stosunku do art. 354 k.c. (Gudowski, Ciepła 2012, 883). Najistotniejszym

${ }^{3}$ Doktryna francuska również przyjmuje pogląd, że naprawienie szkody poprzez najem pojazdu zastępczego stanowi restytucję naturalną, jednak odmiennie traktuje o obowiązku minimalizacji szkody przez poszkodowanego.

${ }^{4}$ Który stanowi, że w razie zajścia wypadku ubezpieczający obowiązany jest użyć dostępnych mu środków w celu ratowania przedmiotu ubezpieczenia oraz zapobieżenia szkodzie lub zmniejszenia jej rozmiarów. 
fragmentem tego przepisu wydaje się ten mówiący o ,użyciu dostępnych środków" przez poszkodowanego do minimalizowania rozmiarów szkody. W literaturze przyjmuje się, że za dostępne należy uznać środki „,nietrudne do zdobycia, osiągalne w danej sytuacji bądź w danych okolicznościach" (Krajewski 2016). Zatem w obliczu obowiązku nałożonego zarówno przez art. 354 k.c. jak i 826 k.c., zdaje się, że wystarczającym jest poinformowanie ubezpieczyciela o samej szkodzie, gdyż sama ta informacja umożliwi mu, jako dłużnikowi, spełnienie świadczenia w postaci zaoferowania pojazdu zastępczego.

Ponadto obowiązek minimalizacji skutków szkody, jak wskazano w wyroku SO w Olsztynie z 24.10.2018 r. (IX Ca 668/18, LEX nr 2585095), musi być utrzymany i stosowany w rozsądnych granicach i nie powinien być wykorzystywany do nakłaniania poszkodowanego, by zrezygnował z realizacji przysługujących mu praw podmiotowych. Owe granice stosowności obowiązku minimalizacji szkody, w sytuacji gdy poszkodowany pokrywa stosunkowo wysokie koszty ubezpieczenia OC, nie powinny w tak znaczącym stopniu, jak wskazano w Uchwale (tj. poprzez obowiązek oczekiwania na ofertę ubezpieczyciela, dłuższy czas oczekiwania na pojazd, obowiązek informacyjny), obciążać poszkodowanego.

\subsection{Sprzeczna treść Uchwały}

SN w Uchwale nie ustrzegł się sprzeczności w jej treści. Pierwsza z nich przejawia się tym, że SN zaznacza, że jeżeli propozycja najmu pojazdu zastępczego obejmowała pojazd o podobnej klasie i ubezpieczyciel zobowiązał się pokryć te koszty w całości, to koszty wyższe powinny zostać pokryte, o ile poszkodowany wykaże ich zasadność, na co może mieć wpływ czas i miejsce podstawienia pojazdu, zasady jego zwrotu czy kwestia konieczności wpłaty kaucji. Zdawać by się więc mogło, że w tym miejscu uzasadnienie jest rozsądne i racjonalne, i nawiązuje do dotychczasowych praktyk. Dalej jednak SN wskazał, że drobne niedogodności o charakterze niemajątkowym (np. nieznacznie dłuższy czas oczekiwania na pojazd zastępczy zaoferowany przez ubezpieczyciela) nie powinny wpływać na decyzję o najmie samochodu od przedsiębiorcy nie związanego $\mathrm{z}$ ubezpieczycielem.

Zestawienie powyższych fragmentów Uchwały już na pierwszy rzut oka wskazuje na obecną w niej sprzeczność. Najpierw SN wskazał, że czas podstawienia pojazdu może być istotnym warunkiem umowy, a co za tym idzie, czynnikiem zezwalającym na najem pojazdu od innego przedsiębiorcy, by następnie posługując się przykładem zaznaczyć, że „drobne niedogodności w zakresie oczekiwania na pojazd" nie mogą o tym decydować. Stwierdzenie to zdaje się być wbrew stanowisku doktryny, w której uznaje się, że właściwość zobowiązania przemawia za niezwłocznym naprawieniem szkody przez osobę odpowiedzialną (Fras, Habdas 2018). 
Argumentem przeczącym tezie o sprzeczności mógłby być teoretycznie fragment mówiący o „drobnych niedogodnościach”, wszak czas oczekiwania sam w sobie jest istotnym warunkiem umowy, jednak gdy jest on ,nieznaczny” stanowi już tylko wspomnianą „,drobną niedogodność”. Problem polega na tym, jak owe pojęcia interpretować. Otóż nietrudno wyobrazić sobie sytuację, w której ubezpieczyciel zaoferuje auto zastępcze następnego dnia po powstaniu szkody, podczas gdy poszkodowany będzie koniecznie potrzebował pojazdu, by dostać się w miejsce, do którego w żaden inny sposób dostać by się nie mógł, a termin, jaki ma na dotarcie w to miejsce upłynie, zanim auto zastępcze od ubezpieczyciela zostanie mu dostarczone. W takiej sytuacji skorzystanie z oferty, która zapewni natychmiastowe dostarczenie pojazdu zastępczego, np. warsztatu, do którego odholowane zostało uszkodzone auto poszkodowanego, wydawałoby się optymalnym rozwiązaniem w tym konkretnym przypadku. Taka oferta może okazać się droższa. W związku z tym poszkodowany będzie miał wybór - zaryzykować i wynająć auto drożej, licząc się z tym, że sąd (bo ubezpieczyciel w trakcie procedury reklamacyjnej z całą pewnością tak) uzna, że przytoczony przypadek stanowi jedynie „drobne niedogodności” i poszkodowanemu nie zostanie zwrócona cała kwota najmu pojazdu zastępczego, albo nie dotrzeć w porę do miejsca, do którego bez trudu dostałby się własnym pojazdem, gdyby ten, co warte zaznaczenia, nie z jego winy, nie został uszkodzony. Niewykluczone też, że sąd przytoczony kazus zinterpretuje jako mieszczący się w kryteriach celowości i ekonomicznej zasadności, jednak SN glosowaną Uchwałą, w przeciwieństwie do ścieżki obranej uchwała III CZP 5/11 z 2011 r. i realizowanej do wydania Uchwały, zdaje się teraz stawiać ubezpieczyciela w uprzywilejowanej sytuacji w przypadku zaistnienia takiego powództwa. Ponadto tego typu sprawy sąd będzie musiał badać indywidualnie i to na poszkodowanym ciążył będzie obowiązek udowodniania, że w danym przypadku nie były to „drobne niedogodności”, ale niedogodności poważne, w dodatku ,celowe i ekonomicznie uzasadnione”. Co za tym idzie, rezultat postępowań będzie dla ich stron czymś w rodzaju loterii, a przecież uchwały SN mają służyć temu, by tego typu loterie ograniczać. W końcu przypadki, w których końcowy i szybki rezultat postępowania da się przewidzieć z prawdopodobieństwem graniczącym z pewnością, wydają się pożądanym środkiem prowadzącym do zmniejszenia liczby postępowań, a także skrócenia czasu trwania tych, które będą się toczyć. Przewidywalność szybkiego rozstrzygnięcia z jednej strony powinna odwieść ubezpieczycieli od odmawiania wypłaty odszkodowań w standardowych sytuacjach, gdyż zważywszy na koszty prowadzenia postępowania i konieczność zapłaty odsetek za opóźnienie w spełnieniu świadczenia, będzie to działanie nieracjonalne ekonomicznie. Powinno to również zniechęcić powodów do wnoszenia roszczeń w sytuacjach, gdy ich szanse powodzenia są nikłe (Krajewski 2016, 38).

Kolejna sprzeczność Uchwały przejawia się w kwestii podstawienia pojazdu zastępczego. Otóż SN wskazał, że ,prostota wynajęcia auta zastępczego w warsztacie naprawczym nie uzasadnia skorzystania z pojazdu pochodzącego 
z wypożyczalni zewnętrznej”, choć we wcześniejszej części uzasadnienia SN podkreślił, że „,czynnikiem, który powinien być brany pod uwagę przy decyzji o wynajęciu pojazdu jest m.in. miejsce jego podstawienia". Zatem na kanwie przytoczonego w poprzednim akapicie niniejszej glosy kazusu, wynajęcie pojazdu w zakładzie naprawczym, który naprawia pojazd poszkodowanego i jednocześnie wynajmuje mu inny samochód zastępczy według SN zasadne nie jest. Sąd zaznacza przy tym, że poszkodowany ma obowiązek skontaktowania się z ubezpieczycielem, a ta czynność nie powinna stanowić dla niego większej trudności, gdyż poszkodowany musi wziąć na siebie częściowo obowiązek minimalizacji szkody. Argumentacja ta w mojej ocenie zasługuje na krytykę, ponieważ w wielu przypadkach ubezpieczyciele nie działają wystarczająco sprawnie i szybko, a oczekiwanie na telefon od przypisanego do sprawy konsultanta trwa nawet kilka godzin. Ten stan rzeczy jest zrozumiały ze względu na skalę działalności ubezpieczycieli i ograniczone zasoby ludzkie (a także materialne w zakresie pojazdów zastępczych, jakie na mocy umów z przedsiębiorcami trudniącymi się najmem pojazdów, które mogą dostarczyć poszkodowanym). Mówiąc wprost, ubezpieczyciel nie jest w stanie traktować poszkodowanego w sposób indywidualny, a stanowisko SN zdaje się zakładać taki wyidealizowany, znacznie odbiegający od rzeczywistości stan faktyczny. Takie indywidualne podejście zaś może zagwarantować inny, zewnętrzny dostawca usługi polegającej na najmie pojazdu zastępczego, dlatego też niezrozumiałym jest, czemu SN utrudnia skorzystanie z jego usług.

\section{PODSUMOWANIE}

Reasumując, jest to kolejna uchwała SN, której w żaden sposób nie można nazwać przełomową, a jedynie potwierdzającą niepewność prawa w kwestii najmu pojazdu zastępczego na czas naprawienia szkody. Zatem trudno zgodzić się ze słowami autorów glosy aprobującej Uchwałę o treści: „omawiana uchwała zdaje się - przynajmniej częściowo - stanowić panaceum na bolączki sądownictwa związane $\mathrm{z}$ dużą liczbą powództw z żądaniem zapłaty odszkodowania obejmującego zwrot wydatków na najem pojazdu. [...] Dla sądów zaś może stanowić wartościowy punkt odniesienia w sprawach, w których pod płaszczem eliminacji negatywnych skutków utraty możliwości korzystania z pojazdu, z roszczeń o zwrot wydatków na najem pojazdu zastępczego czyni się ogólnopolski biznes, niemający nic wspólnego z ochroną interesów poszkodowanych". Gdyż, w moim odczuciu, to nie kolejne uchwały SN powinny kształtować omawianą problematykę, bo też trudno wymagać znajomości treści każdej kolejnej z nich od przeciętnego posiadacza pojazdu, a przepisy, które w jasny i klarowny sposób przyznawałyby poszkodowanemu prawo wynajęcia samochodu zastępczego na czas naprawy. 


\section{BIBLIOGRAFIA}

Fras, Mariusz. Magdalena Habdas. Red. 2018. Kodeks cywilny. Komentarz (art. 363 k.c.) Tom III. Zobowiązania. Część ogólna (art. 353-534). Warszawa: Wolters Kluwer Polska.

Gniewek, Edward. Piotr Machnikowski. Red. 2019. Kodeks cywilny. Komentarz. Wyd. 9. Warszawa: C.H. Beck.

Gudowski, Jacek. Helena Ciepła. 2013. Komentarz KC. Ks. III. Cz. 2. Warszawa: LexisNexis

Kowalewski, Eugeniusz. Michał Ziemiak. 2018. „Glosa do uchwały SN z dnia 24 sierpnia 2017 r., sygn. akt III CZP 20/17”. Orzecznictwo Sąów Polskich 7-8: 39-46.

Koziol, Helmut. Peter Bydlinski. Raimund Bollenberger. Karl-Heinz Danzl. Red. 2017. Kurzkommentar zum ABGB ( $\$ 1323)$. Wien: Verlag Österreich.

Krajewski, Marcin. 2016. Dochodzenie roszczeń o naprawienie szkody w postaci kosztów najmu pojazdu zastępczego $w$ ramach ubezpieczenia OC posiadaczy pojazdów mechanicznych: możliwości ograniczenia liczby lub usprawnienia postępowań sądowych. Warszawa: Instytut Wymiaru Sprawiedliwości.

Krajewski, Marcin. 2016. Umowa ubezpieczenia. Art. 805-834 Kodeksu Cywilnego. Komentarz. Warszawa: C.H. Beck.

Krüger, Wolfgang. Hartmut Oetker. 2012. Münchener Kommentar zum BGB (§ 249). München: C.H. Beck.

Larenz, Karl. 1987. Lehrbuch des Schuldrechts. Erster Band. Allgemeiner Teil. München: C.H. Beck.

Olejniczak, Adam. Red. 2018. Prawo zobowiazań - część ogólna. System Prawa Prywatnego. Tom 6. Warszawa: C.H. Beck.

Osajda Konrad. Witold Borysiak. 2017. Kodeks cywilny. Komentarz (art. 354 k.c.). Wyd. 16. Warszawa: Legalis.

Trzaskowski, Roman. Witold Borysiak. 2016. Dochodzenie roszczeń o naprawienie szkody $w$ postaci kosztów najmu pojazdu zastępczego w ramach ubezpieczenia OC posiadaczy pojazdów mechanicznych (perspektywa prawnoporównawcza). Warszawa: Instytut Wymiaru Sprawiedliwości.

Trzaskowski, Roman. Witold Borysiak. 2017. „Dochodzenie roszczeń o naprawienie szkody w postaci kosztów najmu pojazdu zastępczego w perspektywie prawnoporównawczej”. Prawo w Działaniu. Sprawy Cywilne 31: 43-71.

\section{Orzecznictwo}

Uchwała Sadu Najwyższego z dnia 17 listopada 2011 r., III CZP 5/11, OSNC 2012, nr 3, poz. 28.

Uchwała Sadu Najwyższego z dnia 22 listopada 2013 r., III CZP 76/13, OSNC 2014, nr 9, poz. 85.

Uchwała Sądu Najwyższego z dnia z 30 listopada 2016 r., III CZP 74/16, OSNC 2017, nr 7-8, poz. 82.

Uchwała Sądu Najwyższego z dnia 24 sierpnia 2017 r., III CZP 20/17, OSNC 2018, nr 6, poz. 56.

Wyrok Sądu Okręgowego w Olsztynie z dnia 24 października 2018 r., IX Ca 668/18, LEX nr 2585095. 


\title{
Michat Pytkowski
}

\section{COMMENTARY TO THE RESOLUTION OF THE SUPREME COURT OF 24 AUGUST 2017 (III CZP 20/17) ON THE COMPENSATION OF EXPENSES INCURRED BY THE VICTIM FOR THE LOAN OF A SUBSTITUTE VEHICLE}

\begin{abstract}
In a commentary to the resolution of the Supreme Court regarding the issue of compensation of expenses made on the loan of a substitute means of communication by the victim in a traffic accident, doubts that may arise in the context of case law and practice as well as contradictions in the internal justification of this resolution were indicated. The theoretically correct course of reasoning presented by the Supreme Court presents the arguments derived from the practice and life experience of motor vehicle users, highlighting the idealistic vision of the functioning of the replacement vehicle rental market, presented by the adjudication panel.

Keywords: compensation for expenses for a replacement vehicle, vehicle rental, case law on traffic accidents, cooperation of the insured with the insurer in the settlement of damages, intentional and economically justified expenditure.
\end{abstract}

